\title{
The Settlement for Marriage Dispute Through the Islah in Indonesia
}

\author{
Deity Yuningsih \\ Senior Lecturer at Faculty of Law, Halu Oleo University \\ Address Office : Kampus Bumi Tridharma JL. H.E.A. Mokodompit Kota Kendari, Indonesia 93232 \\ Home: Kompleks Mahkota Permai Blok A2 No. 12B Kendari, Indonesia 93232
}

\begin{abstract}
Islah is an institution of marriage dispute resolution for Moslem communities outside the court which still exists in Indonesia. This paper aims to examine the effectiveness of Islah as one of the institutions for resolving marriage disputes for Muslim communities in Indonesia. For this reason, the type of research used is the type of empirical legal research. This type of research is used to test the behavior of the Indonesian moslem community towards Islah as one of the institutions for resolving marriage dispute. The result of the study shows that the majority of the Indonesian Moslem community still accepts islah as one of the institutions for resolving marriage dispute between them, but in terms of obedience to islah decisions by mediator judges, it has not been fully accepted by the parties to the dispute. Since the Islah ruling is only moral in nature having no legal force that is enforced by law. The author's recommendation, the Indonesian government should make written laws to strengthen the position of Islam, so that it can provide binding power to the parties to the dispute.
\end{abstract}

Keywords: Islah, marriage dispute, Moslem Community

DOI: $10.7176 / \mathrm{JLPG} / 89-07$

Publication date:September $30^{\text {th }} 2019$

\section{Introduction}

Indonesia is one of the countries in the Southeast Asia Region. This country has ethnic and religious diversity, the largest Muslim population. The Indonesian population adheres to religion, which is recognized by the state, namely Islam, Christianity, Hinduism and Buddhism. The adherents of these religions in the interaction of private life with each other, regarding the submission of law, also vary according to their respective beliefs, including the marriage life as part of private life. Marriage that takes place in the lives of Indonesian people, often there are also disputes between husband and wife. Marriage dispute, which continue continuously, will cause disharmony in domestic life. Marriage dispute which is ongoing, for the people of Indonesia must be resolved, in order to maintain a harmonious life between husband and wife and for the sake of education and the development of children's personality in a domestic life.

The results of Nitalia Cipuk Sulistiari's research ${ }^{1}$ on domestic life in Indonesia, say that family life has an influence in determining the development of the character and personality of the child. Family is also the smallest social unit that provides a primary foundation for the development of children in Indonesia. The good and bad family structure has an impact on the good or bad development of the child's personality.

Harmonious household in the structure of Indonesian society can influence the relationship of husband and wife in the household, to be happy, peaceful, and loving partners. Likewise, harmonious household has a positive influence on children's mental development in Indonesia ${ }^{2}$. Dispute in the household will disrupt the harmony of domestic life. The authors' observation from various sources found several factors causing household dispute in Indonesia during 2019, as stated in the following table:

Table 1

Causes of Marriage Disputes in Indonesia in 2015-2018

\begin{tabular}{|c|l|c|}
\hline No & \multicolumn{1}{|c|}{ Causes of Marriage Dispute } & Total \\
\hline 1 & Financial Management in the Household & 200 \\
\hline 2 & Quarrel & 150 \\
\hline 3 & Infidelity & 200 \\
\hline 4 & Intervention of Other Parties & 100 \\
\hline \multicolumn{2}{|c|}{ Total of Respondents } & 650 \\
\hline
\end{tabular}

Data Source: Indonesian Supreme Court 2015-2018

Table data shows that the causes of marriage dispute that befall families in Indonesia are economic factors and quarrels and furthermore are factors of infidelity. Factors that cause the marriage dispute, throughout 2015-

\footnotetext{
${ }^{1}$ Nitalia Cipuk Sulistiari, "Relationship Between Family Harmony and Aggressive Behavior in Adolescents", Thesis Research, Faculty of Psychology, Muhammadiyah University, Surakarta, 2009, p. 3.

${ }^{2}$ N Kardinah, "Family and its Problems Towards A Sakinah Family (Review of Marrital Psychological Perspective", Psymphatic Journal (Scientific Journal of Educational Psychology and Development), 2009, Volume I, Number 1, pp. 109-120.
} 
2018, which afflict domestic life in Indonesia is a reality. The reality of the marriage dispute is interesting to examine in the context of how the model of settlement of marital disputes taken by several families in Indonesia in the life of a pluralistic Indonesian society.

Based on the author's observation in several provinces in Indonesia, it seems that marriage dispute has plagued Muslim families. The Muslim population is the largest population. Marriage dispute which takes place in Moslem families are generally resolved in two ways, namely through the court and through outside the court. What is interesting to observe is the model of dispute resolution taken through outside the court. This path was taken by Moslem families who disputed before the settlement of the dispute was carried out by a judge in a religious court. Settlement of dispute outside the court is usually through mediation, which is called the islah model. In Islamic literature (fiqh), ash-sulhu or islah is categorized as an alternative concept of dispute resolution in the form of an agreement (Aqad) between two people, groups or even disputing countries or disputes to settle or reach agreement between the parties.

According to the author's observation, the resolution of disputes through the Islah path is a way of resolving marriage dispute involving third parties through a mediation model, in which the third party acts as a mediator. The main point of resolving marriage dispute by using the Islah, is peace in which the mediator acts as a peacemaker. What is interesting to be discussed in this study, is that the effectiveness of islah in resolving marriage dispute for Muslim families in Indonesia. Islah capable of being the only savior of marriage for Muslim husband and wife, who are in dispute. This is the research problem discussed by the author in this article.

\section{Research Method Used}

This research is a social research with a legal approach as an analytical tool, so the type of research that is characteristic is the type of empirical legal research. According to Reza Banakar and Max Travers ${ }^{1}$ which empirical legal research is a legal research which tries to analyze legal norms by using the social reality of society as a source of data and as an analytical tool. Likewise, in the opinion of Mukti Fajar and Yulianto Ahmad $^{2}$ that Empirical Legal Research is a legal research method that uses empirical facts taken from human behavior, both verbal behavior obtained from interviews and real behavior carried out through direct observation. Empirical research is also used to observe the results of human behavior in the form of physical and archival relics.

Based on the explanation of the theory, then according to the author that this paper is more suitable using empirical legal research method. The reason is that the causes of marriage disputes are social facts, while the model for resolving marriage dispute pursued by Indonesian society is a legal fact. The discussion which shows the tendency of families in Indonesia to choose a model of dispute resolution in the context of a solution to deal with marriage dispute between them is a legal behavior. This is what is referred to as social research with a legal approach as an analytical tool.

\section{Discussion}

1. Model of Dispute Resolution According to the Legal System in Indonesia

Dispute in the opinion of legal experts in Indonesia, among others, are Nurnaningsih Amriani ${ }^{3}$, which is a situation where there is a party who feels aggrieved by another party, then the party conveys this dissatisfaction to the second party. If the situation shows differences of opinion, then that is called the dispute. In the context of law, especially contract law, what is meant by a dispute is a conflict which occurs between the parties because of a violation of the agreement that has been stated in a contract, both partially and completely. That is, an agreement has been violated by the parties or one of the parties. Dispute is conflict which occur between parties in an agreement because of default made by one party. Also stated by Takdir Rahmadi ${ }^{4}$ who interpreted the dispute as a situation and condition in which people experience factual disputes and disputes that exist only in their perceptions.

In the view of Rudolf Dolzer and Cristoph Schreuer ${ }^{5}$, a dispute is the emergence of disagreement between the parties regarding an act or legal fact or the disagreement of legal views or legal interests between the two parties, as stated in the contract. Based on this explanation, the authors conclude that a dispute is a conflict between the parties in the contractual relationship that arises between them. This dispute can also occur because one of the parties or both parties in the contract has committed a violation or does not fulfill what has become the agreed contract. This conclusion, the author puts the definition of dispute in the context of the understanding of a legal dispute.

In the event of a dispute between the parties arising from the agreement, in general the parties will seek a

\footnotetext{
${ }^{1}$ Reza Banakar dan Max Travers, Theory and Method In Social Legal Research, Hart Publishing, Ireland, p. xi.

${ }^{2}$ Mukti Fajar and Yulianto Ahmad, Dualism Empirical \& Normative Legal Research, Pustaka Pelajar, Jakarta, 2010 , p. 28.

${ }^{3}$ Nurnaningsih Amriani, Mediation Alternative for Settlement of Civil Disputes in the Court, Raja Grafindo Persada, Jakarta, 2012, p. 12-13.

${ }^{4}$ Takdir Rahmadi, Mediation Dispute Resolution Through The Mufakat Approach, Raja Grafindo Persada, Jakarta, 2011, p. 1.

${ }^{5}$ Cristoph Schreuer, Principle of International Investment Law, Second Edition, Oxford University Press, 2008.
} 
solution as a solution for dispute resolution. The definition of dispute resolution, in the opinion of the author, is an effort taken by the parties in the dispute to find a meeting point as one solution that can satisfy the parties or one solution as a forced effort against one party who violates the agreement/contract. In Indonesia, in fact, resolving marriage dispute, especially for Muslim communities, takes two ways, namely through a court and through out of court. The court was taken as the last alternative if the outside court was deemed unable to resolve a marriage dispute between husband and wife. The Indonesian government has established a special court for Muslim communities to resolve marital disputes between husband and wife who adhere to Islam, namely the religious court.

According to Ahmad $\mathrm{R}^{1}$ that The Religious Court in Indonesia was strengthened based on The Act of 7 of 1989 on The Religious Court. According to Yahya Harahap ${ }^{2}$, Law Number 7 of 1989 aims to: (1). Affirming the position and power of the religious court as judicial authority; (2). Creating a unity of the law of the Religious Courts; (3). Purifying the function of The Religious Court. The existence of this Law on The Religious Court, all the old regulations, which regulate The Religious Court were abolished or declared invalid. Based on article 38 to article 42 of Act Number 7 of 1989 that in every religious court there is a seizure. Out of court will be pursued by Muslim communities in Indonesia, before being resolved by court. This pathway is usually called nonlitigation. This resolution of an off-court dispute is generally called Alternative Dispute Resolution (ADR). Article 6 of The Act of 30 of 1999 regulates the choice in resolving disputes through the deliberation of the parties to the dispute, under the title "Alternative Dispute Resolution", which is a translation of Alternative Dispute resolution (ADR). The definition of Alternative Dispute Resolution is an institution for resolving disputes or differences of opinion through a procedure agreed upon by the parties, namely an out-of-court settlement by means of consultation, negotiation, mediation, conciliation or assessment.

In Indonesia, settlement of off-court marriage dispute, known as The Islah. In Islamic knowledge (jurisprudence), ash-sulhu is categorized as the concept of dispute resolution in the form of an agreement (Aqad) between two people, groups or countries in dispute to resolve or reach an agreement between them. Etymologically, The Islah can be interpreted as breaking a dispute. The terminology can be interpreted as a contract agreement made to resolve a dispute. According to the Hambali School ${ }^{3}$ that The Islah is defined as a contract of agreement that functions as a medium to achieve peace between two disputing groups, generally this does not materialize unless the plaintiff is able to be polite until a goal is reached. Some jurists provide almost the same definition even though in a different sense, an easily understood meaning is to break a dispute. In the application that can be understood is a contract with the intention to end a dispute between two disputing people that ends with peace and does not harm one party (win-win solution).

2. Effectiveness of Islah in Settling Marriage Dispute In Indonesia

Settlement of marriage dispute in Indonesia through outside the court, as previously explained, is taken through the Islah Model. This model is carried out by means of mediation that brings together the parties in the dispute in marriage, namely the husband and wife. Appoint one mediator. This mediator is usually a religious figure who truly controls Islamic law about marital issues and is considered to have the capability to resolve marriage dispute in Islamic law.

Islah is commonly used by the people of Indonesia. Islah is in line with the development of community participation. The concept of implementing the Islah assembly is actually very simple, inexpensive and responsive when properly implemented and socialized. It can be assigned to the Indonesian Ulema Council, such as Arbitration, Islamic boarding schools or even mosques and recitation every Sunday morning 4 .

In terms of acceptance of Muslim communities in Indonesia towards Islah as an institution outside the court to settle marital disputes between them, in fact most Indonesian Muslim communities have received it well. The level of acceptance of the Indonesian Muslim community towards Islah is very good. This can be proven from the results of the author's observation of the level of acceptance of Muslim communities in Indonesia towards the Islah itself which the author describe in the following table:

\footnotetext{
${ }^{1}$ Ahmad R, "Religious Courts in Indonesia", Yudisia, Journal of Islamic Law and Legal Thought, Volume 6 Number 2, December 2015, p. 335.

${ }^{2}$ Ibid.

${ }^{3}$ Nitalia Cipuk Sulistiari, op. Cit, p. 10.

${ }^{4}$ Ibid.
} 
Table 2

The level of acceptance of the Indonesian Muslim Community towards The Islah As An Institution Which Resolves Marriage Dispute

\begin{tabular}{|c|l|c|}
\hline No & \multicolumn{1}{|c|}{ Answer Level } & Total of Respondents \\
\hline 1 & Receiving Islah as an institution to resolve marriage dispute & 450 \\
\hline 2 & Accept Islah but with certain requirements & 150 \\
\hline 3 & Don't understand about Islah & 50 \\
\hline \multicolumn{2}{|c|}{ Total of Respondents } & 650 \\
\hline
\end{tabular}

Observation Result in Kendari Region, Indonesia July 2019

The table shows that most of the respondents who are Indonesian Muslim communities living in Kendari City, Southeast Sulawesi Province, have accepted the existence of Islah as a means of resolving marital disputes. Their reasoning that the settlement of marital disputes through islah is very simple than going to court where the time is long, convoluted, and high-cost. For the legal submission of the parties to the dispute over the results of the mediator's decision as a judge in Islah, according to the author's observation, it seems that most of the respondents did not fully comply with the decision. The reason is that Islah's decision has not yet obtained binding legal force in the Indonesian legal system. The decision of an Islah is only moral. Submitted to the disputing party whether or not to accept Islah's decision. The fact of the respondents' disobedience to Islah, the author presents on the following chart:

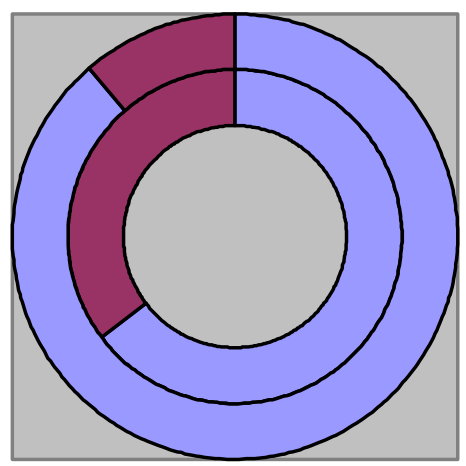

$$
\begin{array}{|l|}
\square 50 \\
\square 300
\end{array}
$$
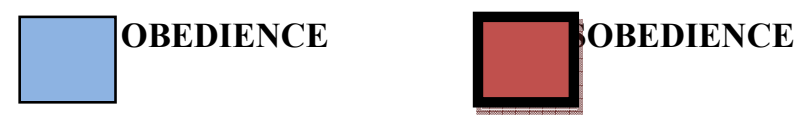

Observation Result in Kendari Region, Indonesia July 2019

Respondents who were disobedient, went to court to resolve marriage dispute between them. The court was then taken because one of the parties was not satisfied with the results of the decision by the mediator as the judge in the Islah. This shows that the institution is one way to resolve marital disputes for Muslim communities in Indonesia, not yet effective in terms of their legal submission in the decision of Islah.

\section{Closing}

Islah has become one of the out-of-court marriage dispute resolution institution chosen by Muslim communities in Indonesia. The Indonesian Muslim community has accepted Islah as one of the settlement of marriage dispute. In this regard, it is quite effective to be accepted as an institution to settle marriage dispute. In terms of the legal submission of the Indonesian Muslim community, the decision produced by Islah are not fully adhered to its. This is because the islah decision in the Indonesian legal system does not yet have strong legal force. Decision of Islah is still moral. This is what makes the Islah ruling not yet effective in providing binding power to the parties to the dispute to obey it.

The author recommends that the Islah institution as one of the institutions for resolving marriage dispute in Indonesia, be strengthened through special act by the Indonesian government and the Indonesian House of Representatives. So that Islah as an institution for resolving marital disputes can be an effective binding force for those who choose it as one of the institutions for resolving marriage disputes.

\section{References}

1) Nitalia Cipuk Sulistiari, "Relationship Between Family Harmony and Aggressive Behavior in Adolescents", Thesis Research, Faculty of Psychology, Muhammadiyah University, Surakarta, 2009, p. 3. 
2) N Kardinah, "Family and its Problems Towards A Sakinah Family (Review of Marrital Psychological Perspective", Psymphatic Journal (Scientific Journal of Educational Psychology and Development), 2009, Volume I, Number 1, pp. 109-120.

3) Reza Banakar dan Max Travers, Theory and Method In Social Legal Research, Hart Publishing, Ireland, p. xi.

4) Mukti Fajar and Yulianto Ahmad, Dualism Empirical \& Normative Legal Research, Pustaka Pelajar, Jakarta, 2010, p. 28.

5) Nurnaningsih Amriani, Mediation Alternative for Settlement of Civil Disputes in the Court, Raja Grafindo Persada, Jakarta, 2012, p. 12-13.

6) Takdir Rahmadi, Mediation Dispute Resolution Through The Mufakat Approach, Raja Grafindo Persada, Jakarta, 2011, p. 1.

7) Cristoph Schreuer, Principle of International Investment Law, Second Edition, Oxford University Press, 2008.

8) Ahmad R, "Religious Courts in Indonesia", Yudisia, Journal of Islamic Law and Legal Thought, Volume 6 Number 2, December 2015, p. 335. 